\title{
Effect of endoparasites occurrence in sows from intensive production system
}

\author{
Efeito da ocorrência de endoparasitas em matrizes suínas de sistema de produçáo intensivo \\ Newton Tavares Escocard de Oliveira ${ }^{1}$; Paulo Levi de Oliveira Carvalho'; Jansller Luiz Genova ${ }^{1 *}$ (1); \\ Fábio Henrique Rodrigues Silveira ${ }^{1}$; Liza Ogawa ${ }^{2}$; Eliseu Carlos Cristofori ${ }^{1}$; Osíris Antunes de Caxias Junior ${ }^{1}$; \\ Ana Lúcia Almeida Santana ${ }^{3}$

\begin{abstract}
${ }^{1}$ Universidade Estadual do Oeste do Paraná - UNIOESTE, Marechal Cândido Rondon, PR, Brasil
${ }^{2}$ Setor de Medicina Veterinária e Produção Animal, Universidade Estadual do Norte do Paraná - UENP, Bandeirantes, PR, Brasil
\end{abstract} \\ ${ }^{3}$ Universidade Federal dos Vales do Jequitinhonha e Mucurí - UFVJM, Unaí, MG, Brasil
}

Received September 26, 2019

Accepted October 10, 2019

\begin{abstract}
The goal of this study was to assess the effect of farm size (FS) and farrowing order (FO) on the occurrence of endoparasites eggs in commercial sows housed in maternity and gestation areas during the period from May to July 2014. Forty-three piglet production units were classified by FS: small (100 to 250 sows), medium (251 to 510 sows), large (511 to 1,000 sows) and very large (more than 1,000 sows). Sows were classified by FO: up to two, three to five or more than five parturitions. Faecal samples were processed using the simple flotation technique in a hypersaturated salt solution $(30-35 \% \mathrm{NaCl})$. The results revealed that the overall prevalence of gastrointestinal endoparasites obtained in this study was $12.47 \%$, in that $4.64 \%$ were positive for Ascaris suum, $0.56 \%$ for Trichuris suis and $8.27 \%$ for coccidia oocysts. The prevalence of endoparasites obtained for small and medium size farm, and for large and very large farm was $34.58 \%$ and $15.52 \%$, respectively. In conclusion, the study shows that more than half of the farms were positive for A. suum and coccidia oocysts, but mainly for younger females. In general, sows with up to two parturitions and small farms showed a higher endoparasites percentage.
\end{abstract}

Keywords: Ascaris suum, Eimeria, farm size, parturition order, pig, Trichuris suis.

\section{Resumo}

O objetivo deste estudo foi o de avaliar o efeito de tamanho de granja (TG) e a ordem de parição (OP) sobre a ocorrência de ovos de endoparasitas em matrizes suínas comerciais alojadas na maternidade e gestação durante o período de maio a julho de 2014. Quarenta e três unidades produtoras de leitóes foram classificadas por TG: pequena (100 a 250 porcas), média (251 a 510 porcas), grande (511 a 1.000 porcas) e muito grande (mais de 1.000 porcas). As porcas foram classificadas por OP: até dois, três a cinco e mais que cinco partos. As amostras fecais foram processadas usando a técnica de flotaçáo em soluçáo salina hipersaturada a 30-35\%. Os resultados revelaram que a prevalência global de endoparasitas gastrointestinais obtidos neste estudo foi de $13,59 \%$, em que 4,64\% foram positivas para Ascaris suum, 0,56\% para Trichuris suis e 8,27\% para oocistos de coccídeos. A prevalência de endoparasitas obtidos para fazendas de pequeno e médio porte, e para fazendas grandes e muito grandes foi de $34,58 \%$ e $15,52 \%$, respectivamente. Em conclusão, o estudo mostra que mais da metade das fazendas foram positivas para $A$. suum e oocistos de coccídeos, mas principalmente para as fêmeas mais jovens. Em geral, as porcas com até dois partos e pequenas propriedades mostraram uma porcentagem maior de endoparasitas.

Palavras-chave: Ascaris suum, Eimeria, tamanho de granja, ordem de parto, suíno, Trichuris suis.

*Corresponding author: Jansller Luiz Genova. Programa de Pós-graduação em Zootecnia - PPZ, Universidade Estadual do Oeste do Paraná - UNIOESTE, Rua Pernambuco, 1777, Marechal Cândido Rondon, CEP 85960-000, PR, Brasil. e-mail: jansllerg@gmail.com 


\section{Introduction}

Production indices indicate that the Brazilian swine market has been growing gradually. Despite being among the best in the world, there is still much to develop and improve, a fact that presents opportunities for new scientific research and agribusiness development. Pig farming is a great choice from a social and economic point of view, since it is considered a strong activity for the supply of high-quality animal protein. Additionally, it provides raw material for cold storage industries and numerous jobs.

Some diseases can hinder satisfactory productive rates. Among them, gastrointestinal and pulmonary parasites receive extensive exploration worldwide. These diseases present health problems during all pig farming phases and are generally more associated with extensive breeding. Parasitised females are a source of infection for piglets via colostrum; larvae eggs attached to the skin of the mammary gland skin may also be ingested by the suckling piglets (KARAMON et al., 2007).

Despite the emphasis on the use of technology and sanitary management, pigs are still infected by many endoparasites even in locations with good management practices. In industrial breeding, the problems that arise from helminthiases are relevant and result in losses that need to be accounted for and analysed so that the pig industry can establish more effective control measures (KNECHT et al., 2011). However, since there are few studies on helminth infections in industrial pig farms further investigation is required.

In industrial breeding systems, Ascaris suum is the most important and prevalent helminth species in pigs (VLAMINCK et al., 2014). According to Pittman et al. (2010), Trichuris suis is present in modern pig systems, but it represents an unusual diagnosis and may be overlooked. In reports by Gagman et al. (2014), T. suis was common in store pigs but not often found in other groups. Some authors relate the occurrence of Eimeria spp. in pigs as an indicator of the hygienic state of a farm; it is particularly prevalent in places with poor sanitary status (KARAMON et al., 2007).

Research to assess the influence of endoparasites in pig production reported effects such as severe diarrhea, anorexia and growth performance losses (PITTMAN et al., 2010), high morbidity and mortality in productivity and reproductive performance of pigs associated with helminth infections (NISSEN et al., 2011), growth deficits (VLAMINCK et al., 2014) and expressive reproductive losses and low reproductive performance (KARAYE et al., 2016). Thus, the goal of this study was to assess the effect of farm size (FS) and farrowing order (FO) on the occurrence of endoparasites eggs from A. suum, T. suis and Oesophagostomum sp. and oocysts from Eimeria sp. in commercial sows (part of intensive production systems) housed in maternity and gestation sheds.

\section{Materials and Methods}

\section{Study design}

Formal ethical approval is not required in Brazil for studies based on faecal samples. However, informed consent was requested from farmers who volunteered to participate in the study, and all results were reported directly to farmers. The authors declare that they have no conflict of interest. The study was carried out in 43 piglet production units (PPUs) located in the cities of Pato Bragado, Entre Rios do Oeste, Mercedes, Toledo, Quatro Pontes and Marechal Cândido Rondon, located in the western part of the state of Paraná, Brazil, during the period from May to July 2014.

The PPUs were classified into 4 categories according to FS (number of sows): 23 small farms (between 100 and 250) with 4,097 total sows, 11 medium farms (251 to 510) with 3,854 total sows, 6 large farms $(511$ to 1,000$)$ with 4,054 total sows and 3 very large farms (more than 1,000) with 5,120 total sows. Overall, the herd size was 17,125; sows were classified by FO into three categories: up to two parturitions $\left(\mathrm{FO}_{1}\right)$, three to five parturitions $\left(\mathrm{FO}_{2}\right)$ and more than five parturitions $\left(\mathrm{FO}_{3}\right)$.

\section{Faecal sample collections and processing}

Faecal samples were collected randomly in several regions within gestation and maternity sheds from $10 \%$ of the sows on small and medium farms ( $\mathrm{n}=400$ and 384, respectively) and from $8 \%$ of the sows housed in large and very large farms $(n=411$ and 401 , respectively). The faeces were collected fresh into sterile specimen bottles with the aid of a glove and transported in isothermal boxes containing ice to laboratory for parasitological examination. The faecal samples were first examined macroscopically for any parasites in the laboratory before processing for microscopical examination. For each farm, a report was filled out with individual data about the properties and the sows.

Quantification of the number of eggs per gram (EPG) of faeces and number of oocysts per gram (OPG) of parasites in faeces was performed according to the technique of Gordon and Whitlock (modified), described by Ueno \& Gonçalves (1998). Faecal samples were weighed $(2 \mathrm{~g})$ and then added to $58 \mathrm{~mL}$ of hypersaturated salt solution. Subsequently, the solution was homogenised, sieved with the support of gauze and an aliquot of the suspension was collected and used to fill the McMaster chamber. After 1-2 min, the suspension was observed under a microscope with a $10 \mathrm{x}$ objective and endoparasites eggs counted. The number obtained for each parasite was summed up in the two cells of the chamber and the result was multiplied by the correction factor 50 (UENO \& GONÇALVES, 1998).

\section{Statistical analysis}

Prevalence of total endoparasite eggs, individual percentage of occurrence of $A$. suum, T. suis, Oesophagostomum spp. (O. spp.) and oocysts from the genus Eimeria (OEI), as well as the logarithm (base ten) of (EPG + 1) of faeces for A. suum (LOGEPGAS), T. suis (LOGEPGTS) and OPG of faeces for endoparasites from the genus Eimeria (LOGEPGOEI) were evaluated.

Statistical analysis was performed by adjustment the Generalised Additive Models for Location, Scale and Shape (GAMLSS). The maximum penalized likelihood method was used to estimate the model parameters. For characteristics expressed by binary values, GAMLSS was adjusted with binomial distribution and logit binding function: $g(\mu)=\log (\mu / 1-\mu)$. For the data expressed by the logarithm of endoparasite +1 counts, the GAMLSS was adjusted to the zero-inflated Poisson (ZIP) distribution, which has the binding function $\mathrm{g}(\mu)=\log$, for modeling of $\mu$, and $\mathrm{g}$ $(\mu)=$ logit, for modeling of $\sigma$. The GAMLSS used was represented 
by the systematic portion $\eta=\mu+\mathrm{FS}_{\mathrm{i}}+\mathrm{FO}_{\mathrm{j}}+\mathrm{FS} * \mathrm{FO}_{\mathrm{ij}}$, where $\mu$ was the effect of the general average, $\mathrm{FS}_{\mathrm{i}}$ was the effect of farm size classes ( $\mathrm{i}=1,2,3$ and 4$), \mathrm{FO}_{\mathrm{j}}$ was the effect of farrowing order classes ( $j=1,2$ and 3$), F S * \mathrm{FO}_{\mathrm{ij}}$ was the interaction effect between the $i$-th FS and the $j$-th FO.

The significance of the coefficients associated with FS, FO and the interaction between FS and FO was verified with the deviance difference test between two models or type I analysis using the Wald statistic. The fit quality of the adjusted model was verified by the lower value of the Akaike information criterion together with a graphical analysis of the model residues, evaluated using the worm plot procedure of $\mathrm{R}$ program.

The observed proportions of total endoparasite eggs, A. suum, T. suis and oocyst coccidia related to the interaction between FS and FO, and which were expressed by the hierarchical effects of FS given FO and of FO given FS, were compared using a bilateral test of proportions equality with Yates' continuity correction.

The observed averages of the log of the endoparasites counts +1 , related to the interaction effect between FS and FO, were compared by orthogonal contrasts related to the unfolding of the global deviance difference and the respective degrees of freedom, namely the chi-square statistic.

A 5\% level of significance was adopted as the hypothesis for all statistical tests. Statistical analyses were performed using the procedures of the R Core Team's GAMLSS package (R Core Team 2018) and SAS ${ }^{\oplus}$ University Edition software (SAS, 2019).

\section{Results}

The results revealed that the overall prevalence of gastrointestinal endoparasites obtained in this study was $12.47 \%$. The prevalence of endoparasites obtained for small and medium size farm and for large and very large farm was $34.58 \%$ and $15.52 \%$, respectively. From a total of 1,596 sow faecal samples, $73(4.57 \%)$ were positive for A. suum, $9(0.56 \%)$ contained T. suis and 135 (8.46\%) had oocyst coccidia. Of the 43 farms we examined, $25(58.14 \%)$ presented positive samples for A. suum, 3 (6.98\%) for T. suis and $30(69.77 \%)$ for coccidia oocysts.

There was an interaction effect between FS and FO on the proportion of total endoparasite eggs $(\mathrm{p}=0.0067)$. For the percentage of $A$. suum, T. suis eggs and Eimeria oocysts, the interaction effect between FS and FO were $\mathrm{p}=0.0797, \mathrm{p}=1.0000$ and $\mathrm{p}=0.0971$. In farms with up to 1,000 sows, the incidence of $A$. suum and total endoparasite eggs was higher $(\mathrm{p}<0.0001)$ in younger females with at most two parturitions $\left(\mathrm{FO}_{1}\right)$, than in sows with more than two $\left(\mathrm{FO}_{2}\right.$ and $\left.\mathrm{FO}_{3}\right)$. This result shows that female age inversely influences the proportion of samples positive for these endoparasites. The highest intensities were 19.42 \pm 1.70 (A. suum) and $38.13 \pm 2.67 \mathrm{EPG}$ in sows with up to two parturitions housed in small farms (up to 250 sows).

For this FS, we observed a significant difference $(\mathrm{p}<0.0001)$ in the incidence of $A$. suum and total endoparasite eggs between sows classified with three to five parturitions (A. suum: $6.90 \pm 1.66 \%$ and total endoparasite eggs: $17.24 \pm 2.62 \%$ ) compared to sows with more than five parturitions ( $A$. suum: $0.86 \pm 1.86 \%$ and total endoparasite eggs: $1.72 \pm 2.93 \%$ ) (Figure 1 ).

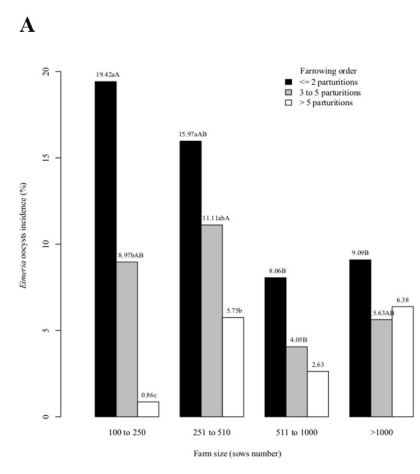

B

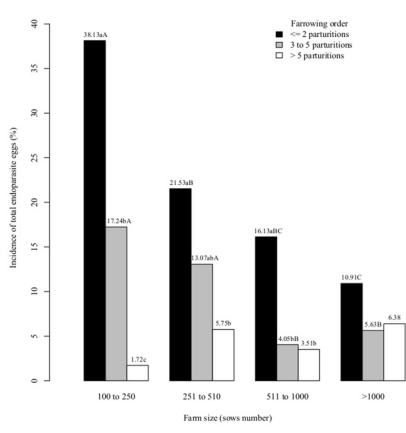

C
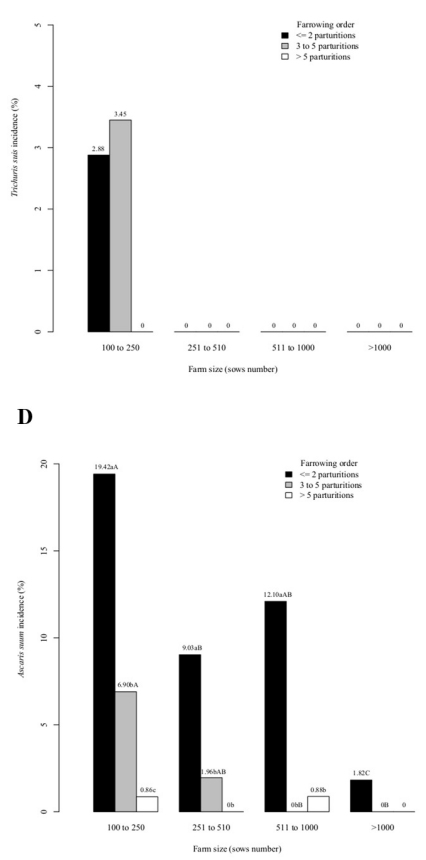

Figure 1. Observed averages of the incidence (\%) of A. suum, T. suis, Eimeria and totals in sows according to the farrowing order and farm size. Observed proportions followed by different lowercase letters in the column for the effect of FO given FS (FO/FS), and by different capital letters in the row for the effect of FS given FO (FS/FO), differ from each other by the bilateral test of proportions equality with Yates' continuity correction, at a 5\% probability level. (A) = Eimeria oocysts incidence (\%), (B) = Incidence of total endoparasite eggs $(\%),(\mathbf{C})=T$. suis incidence $(\%)$ and $(\mathbf{D})=A$. suum incidence $(\%)$ FO: farrowing order, $\mathrm{FO}_{1}$ : sows with a maximum of two parturitions, $\mathrm{FO}_{2}$ : sows with three to five parturitions, $\mathrm{FO}_{3}$ : sows with more than five parturitions. 
There were no differences $(\mathrm{p}>0.05)$ in the proportions of A. suum, $T$. suis, Eimeria oocysts and total endoparasite eggs among sows with different parturition orders from very large farms composed of more than 1,000 sows (Figure 1). There was a low occurrence of positive samples for T. suis in females with up to two parturitions $(2.88 \pm 0.63 \%)$ and with three to five parturitions $(3.45 \pm 0.61 \%)$ on small farms. However, these percentages were higher than the incidence of $T$. suis in females with more than five parturitions (0\%) (Figure 1). This result indicates that there is a wide range of endoparasite occurrence.

Despite a $p$ value of 0.097 for the interaction effect on the proportion of Eimeria oocysts, on small farms a higher proportion ( $p=0.001)$ of oocysts was observed in females with up to two parturitions $(19.42 \pm 1.70 \%)$ compared to those with higher farrowing orders $(8.97 \pm 2.27$ and $0.86 \pm 2.54 \%$, respectively). In medium farms (251 to 510 sows), females with up to two parturitions $(15.97 \pm 2.28 \%)$ had a significantly higher proportion ( $p=0.001)$ of oocysts compared to females with more than five parturitions $(5.75 \pm 2.93 \%)$. Indeed, the FO effect was not significant $(\mathrm{p}>0.05)$ for large (511 to 1,000 sows) or very large (more than 1,000 sows) farms. The proportions ranged from $2.63 \pm 2.56 \%\left(\mathrm{FO}_{3} / \mathrm{FS}_{3}\right)$ to $9.09 \pm 2.13 \%$ for $\mathrm{FO}_{1} / \mathrm{FS}_{4}$ (Figure 1 ).

For sows that had a maximum of five parturitions $\left(\mathrm{FO}_{1}\right.$ and $\left.\mathrm{FO}_{2}\right)$, the incidence of $A$. suum was higher $(\mathrm{p}<0.05)$ for sows housed on small farms compared to very larger farms. This result was also obtained for total endoparasite eggs, considering sows with a maximum of two parturitions (Figure 1). For sows with three to five parturitions $\left(\mathrm{FO}_{2}\right)$, a higher proportion $(\mathrm{p}<0.05)$ of total endoparasite eggs was observed for sows housed on small and medium farms compared to sows housed on large and very large farms. However, if $\mathrm{FO}_{2}$ sows were included, the Eimeria oocyst incidence was higher $(\mathrm{p}<0.05)$ for sows housed on average farms $(11.11 \pm 2.21 \%)$ than sows housed in large farms $(4.05 \pm 2.08 \%)$ (Figure 1).

No differences $(p>0.05)$ were found for the proportions of A. suum, T. suis, Eimeria oocysts and total endoparasite eggs among sows housed on different farm sizes, for sows with more than five parturitions (Figure 1). There was an interaction effect between FS and FO for LOGEPGAS ( $p<0.01)$, LOGEPGTS $(\mathrm{p}=0.007)$ and LOGEPGOEI $(\mathrm{p}=0.074)$. However, for LOGEPGOEI there was an effect $(\mathrm{p}=0.017)$ of FO (Table 1$)$.

\section{Discussion}

Although lower occurrence rates among sows were found in this study, parasitism should still maintain great importance in intensive pig farming because it can persist on farms with good hygiene practices due to faecal-oral transmission between females and/or the lactating sow and the piglet. Additionally, eggs are resistant and exhibit high survival even in production systems with concrete floors. In addition, there are few studies that relate FO and endoparasite occurrence in sows. In 532 pigs examined, Gagman et al. (2014) reported an incidence of $9.77 \%$ for $A$. suum and $7.52 \%$ for T. suis. That $A$. suum incidence was $113.78 \%$ higher than that found in our study. Therefore, the occurrence and/or prevalence of a particular endoparasite is directly related to the production system, breeding stage and sampling site.

In addition, the lack of an effective control system would require more information on the epidemiological pattern, the availability of the new anthelmintics and the better education of the producers (TAMBOURA et al., 2006). Comparatively, Katakam et al. (2016) found the occurrence of $A$. suum was $15 \%$ for lactating sows, a lower value than that obtained by Nissen et al. (2011) with growing pigs (39.6\% for $A$. suum). It is possible that the greater $A$. suum prevalence observed compared the results of other surveys can be explained by the fact that the sows are housed in pens with entirely concrete floors, and thus they were in direct contact with faeces.

Several endoparasites species were recorded in pig research. Eggs infected by Hyostrongylus sp., Oesophagostomum spp., Strongyloides sp. and Trichuris sp. were reported by D'Alencar et al. (2011). Pinto et al. (2007) identified, among the helminths, eggs from Oesophagostomum spp., A. suum, Metastrongylus salmi, Macracanthorynchus hirudinaceus and T. suis. A total of 10,000 coccidia oocysts, 1,500 A. suum eggs and one T. suis occurrence were identified in 200 breeding females (HOFF et al., 2005). The high prevalence of coccidia is related to poor efficiency

Table 1. Observed averages and standard deviation (in parentheses) of the log (LOG) of the number of helminth eggs per gram (EPG +1 ) of feces and the log of the number of oocysts of the genus Eimeria per gram of feces (OPG) in sows according to the farrowing order and farm size ${ }^{1}$.

\begin{tabular}{|c|c|c|c|c|c|}
\hline \multirow{2}{*}{ Item } & \multirow{2}{*}{ FO } & \multicolumn{4}{|c|}{ Farm size $(\mathrm{FS})$} \\
\hline & & 100 to 250 sows & 251 to 510 sows & 511 to 1,000 sows & $>1,000$ sows \\
\hline \multirow[t]{3}{*}{ LOGEPGAS } & $\mathrm{FO}_{1}$ & $0.504(1.055)^{\mathrm{aA}}$ & $0.237(0.773)^{\mathrm{aA}}$ & $0.250(0.686)^{\mathrm{aA}}$ & $0.036(0.269)^{\mathrm{B}}$ \\
\hline & $\mathrm{FO}_{2}$ & $0.159(0.601)^{\mathrm{aA}}$ & $0.053(0.376)^{\mathrm{bB}}$ & $0(0)^{\mathrm{bC}}$ & $0(0)^{\mathrm{C}}$ \\
\hline & $\mathrm{FO}_{3}$ & $0.017(0.186)^{\mathrm{b}}$ & $0(0)^{\mathrm{c}}$ & $0.015(0.160)^{\mathrm{b}}$ & $0(0)$ \\
\hline \multirow[t]{3}{*}{ LOGEPGTS } & $\mathrm{FO}_{1}$ & $0.065(0.380)^{\mathrm{aA}}$ & $0(0)^{\mathrm{B}}$ & $0(0)^{\mathrm{B}}$ & $0(0)^{\mathrm{B}}$ \\
\hline & $\mathrm{FO}_{2}$ & $0.086(0.457)^{\mathrm{aA}}$ & $0(0)^{\mathrm{B}}$ & $0(0)^{\mathrm{B}}$ & $0(0)^{\mathrm{B}}$ \\
\hline & $\mathrm{FO}_{3}^{2}$ & $0(0)^{\mathrm{b}}$ & $0(0)$ & $0(0)$ & $0(0)$ \\
\hline \multirow[t]{3}{*}{ LOGEPGOEI } & $\mathrm{FO}_{1}$ & $0.501(1.064)^{\mathrm{a}}$ & $0.385(0.929)$ & $0.180(0.646)$ & $0.199(0.652)$ \\
\hline & $\mathrm{FO}_{2}$ & $0.214(0.704)^{a}$ & $0.251(0.736)$ & $0.088(0.441)$ & $0.136(0.590)$ \\
\hline & $\mathrm{FO}_{3}$ & $0.019(0.202)^{\mathrm{b}}$ & $0.119(0.492)$ & $0.049(0.302)$ & $0.138(0.557)$ \\
\hline
\end{tabular}

${ }^{1}$ Observed averages followed by different lowercase letters in the column for the effect of FO given FS (FO/FS), and by different capital letters in the row for the effect of FS given FO (FS/FO), differ from each other by orthogonal contrasts related to the unfolding of the global deviance difference and the respective degrees of freedom, namely the chi-square statistic, at a $5 \%$ probability level. 
of sanitary management or a lack of sanitary management and adoption of biosecurity practices.

Joachim \& Daugschies (2000) reported that sows are predominantly infected by Oesophagostomum spp., A. suum and Eimeria sp., with a minor proportion for T. suis, Hyostrongylus rubidus, Strongyloides ransomi and Isospora suis. Similarly, these findings corroborate with those reported in this study. Nissen et al. (2011) reported that Oesophagostomum spp. are favoured by high faecal egg excretion, and the free-living stages thrive particularly in moist and unhygienic conditions, similar to other endoparasites with a faecal-oral transmission cycle.

In our study, we did not identify any Oesophagostomum spp. occurrences, a finding that indicates the examined farms had favourable hygienic conditions for the sows. Susceptibility to parasitic infections may be related to the female life-cycle period (in this study either peri- or postpartum); that is, they were physiologically fragile due to birth or the piglet suckling period (VAZ et al., 2014).

Karaye et al. (2016) analyzed 50 faecal samples from pigs and obtained a prevalence of $13.5 \%$ for $A$. suum, while T. suis cysts and Oesophagostomum spp. oocyst prevalence was $2.5 \%$. The authors attributed the high recorded prevalence to inadequate measures of animal husbandry and biosecurity, and differences in helminth prevalence may also be associated with differences in environmental conditions, stocking rate and the nature of the immunity status of the diet. These results differ from those obtained in our study because all the farms presented a biosecurity system. According with the authors, the low prevalence of intestinal endoparasites may be the result of effective farm management practices, such as daily cleaning and pen disinfecting, high-quality commercial foods and the use of effective anthelmintic drugs at the right time.

The susceptibility of young females to $A$. suum, especially on small farms, was greater from birth until about four months, common in growing pigs, but subsequently decreased, a possible reason why the endoparasites were infrequent in animals older than two years (THAMSBORG \& ROEPSTORFF, 2003). This fact explains why the sows with greater farrowing order and/or older presented lower susceptibility. The infection percentage becomes more discreet as the sow age increases. Ascariasis in farms depends mainly on pigs aged between three and six months. Deworming medication-based treatment becomes of the utmost importance for newly acquired gilts on the properties where they are housed (FRONTERA et al., 2005).

In contrast to our research, Sowemimo et al. (2012) reported a prevalence of $11.1 \%$ for $A$. suum in 271 pigs examined in the Nigeria. In addition, the prevalence of intestinal endoparasites was higher in male $(45.0 \%)$ than in female $(30.4 \%)$ pigs. The $A$. suum prevalence may be as a result of ineffective anthelmintic administered on farms of origin before transport to the final destination, and action which can consequently lead to farm contamination. It is possible that sows raised on small farms received lower anthelmintic control compared to other farms because they showed a highest endoparasites prevalence.

With regards to the $T$. suis incidence, there are few reports in the literature of its occurrence in sows because of inefficiency or inability to identify them with the techniques normally used, difficult access to animals in contaminated areas or due to very low occurrence. The above reasons could explain our results, where the endoparasite was only identified in 3 of 43 farms. Indeed, Perfetti et al. (2013) reported a T. suis prevalence of $1.68 \%$.

An incidence of $0.2 \%$ for T. suis, $1 \%$ for Strongyloidea and 3.4\% for Hyostrongylus sp. was obtained from faeces samples from finishing pigs raised on farms with technology. These positive percentages were lower $(p<0.05)$ compared to the respective incidences from pigs raised on subsistence farms (D'ALENCAR et al., 2011). The authors reported that the frequency of these endoparasites was directly related to handling, hygiene and worming and on the floor type.

The $T$. suis prevalence may result from the ability of the eggs to survive for a long time in the environment (PITTMAN et al., 2010). It is also possible that the variation between the surveys reflects an effect of weather extremes and hygiene conditions that may have favored or impaired eggs (KATAKAM et al., 2016). The low current incidences and faecal egg counts were different to those reported in a previous survey carried out by Lai et al. (2011) in intensive system farms in the China with $20.25 \%$ (A. suum), 6.54\% (T. suis) and $13.40 \%$ (Oesophagostomum spp.), and $11.84 \%$ for Eimeria spp.

According to Gagman et al. (2014), this can be attributed because young pigs that are still suckling or weaned have greater immunity to parasitic infections than adults. This fact is related to the antibodies that are provided in the female pig milk during the suckling phase. Later, the older female pigs have a health condition due to acquired immunity towards gilts, which is indicative of the results found in our study regarding the farrowing order.

Nejsum et al. (2009) reported that in infected herds, growing young pigs have the highest prevalence, while the sows are rarely infected. Independent of FS, the absence of $T$. suis in sows with more than five parturitions was unexpected, since the eggs are very resistant in the environment and can remain viable for more than two years in pastures and six years in rural facilities (RADOSTITIS et al., 2007). Although they infect pigs of all ages, these nematodes are more frequent in animals aged less than six months (ALCAIDE et al., 2005), which is in accordance with our findings.

Research on Eimeria prevalence in pig production is old and requires further investigation. This prevalence is related to a lower level of hygiene on the farm. In our study we verified that the prevalence of Eimeria is directly related to the farrowing order and farm size. Karamon et al. (2007) found oocysts of I. suis and Eimeria spp. in $18(6.7 \%)$ and $16(6 \%)$ of the 267 sows examined, respectively. Endoparasites of the genus Eimeria present a cosmopolitan distribution, and it is estimated that 60 to $90 \%$ of pigs are carriers (CORDERO DEL CAMPILLO \& ROJO VÁSQUEZ, 1999). The diseases occur mainly in young animals, but parasitism is frequent in adults (RADOSTITIS et al., 2007).

Overall, there is a need for combined efforts to control endoparasite infections in pig study areas for the ideal production of pigs. Although there was a low endoparasite prevalence in sows, at least one endoparasites species was detected at all farms, a finding that demonstrates the persistence of parasitism in the breeding units.

In conclusion, the results of this study suggest that sows with a maximum of two parturitions housed on small farms, composed 
of 100 to 250 sows, have a higher incidence of endoparasites than sows with a higher farrowing order housed on farms with more than 250 sows. Small and medium sized farms presented a higher percentage of endoparasites compared to large and very large farms. Therefore, there is a need for combined handling to control endoparasite infections in sows for better production.

\section{References}

Alcaide M, Frontera E, Rodríguez MJ, Sáenz IE, Domínguez-Alpízar JL, Reina D, et al. Parasitosis pulmonares del cerdo ibérico: situación actual de la metastrongilosis en Espańa. Rev Mundo Ganad 2005; 16(176): 40-44.

Cordero del Campillo M, Rojo Vásquez FA. Eimeriosis e Isosporosis. In: Cordero del Campillo M, Argüelo MRH, Baños ND. Parasitología veterinária. 1st ed. Madrid, Espańa: McGraw-Hill-Interamericana de España S.A.U; 1999. p. 451-456.

D’Alencar S, Farias MPO, Rosas EO, Lima MM, Alves LC, Faustino MAG. Influência do manejo higiênico-sanitário na infecção por helmintos gastrintestinais em suínos de granjas tecnificadas e de subsistência abatidos na região metropolitana de Recife e Zona da Mata do estado de Pernambuco, Brasil. Arq Inst Biol 2011; 78(2): 207-215.

Frontera E, Alcaide M, Domínguez-Alpízar JL, Boes J, Reina D, Navarrete I. Evidence of interaction between Ascaris suum and Metastrongylus apri in experimentally infected pigs. Vet Parasitol 2005; 127(3-4): 295-301. http://dx.doi.org/10.1016/j.vetpar.2004.11.001. PMid:15710530.

Gagman HA, Ajayi OO, Abubakar BM. Occurrence of gastro-intestinal helminths of pigs slaughtered at the Jos Abattoir, Plateau state, Nigeria. BAJOPAS 2014; 7(2): 17-20.

Hoff G, Silva AS, Monteiro SG. Avaliação do parasitismo e comparação de técnicas de análise fecal em suínos de granjas da região oeste do estado de Santa Catarina. Rev FZVA 2005; 12(1): 106-115.

Joachim A, Daugschies A. Endoparasites in swine in different age groups and anagement systems. Berl Munch Tierarztl Wochenschr 2000; 113(4): 129-133. PMid:10816911.

Karamon J, Ziomko I, Cencek T. Prevalence of Isospora suis and Eimeria spp. in suckling piglets and sows in Poland. Vet Parasitol 2007; 147(1-2): 171-175. http://dx.doi.org/10.1016/j.vetpar.2007.03.029. PMid:17467906.

Karaye GP, Dogo AG, Iliyasu D, Madu HK. Prevalence of swine gastrointestinal parasites in four selected local government areas of Nasarawa State, Nigeria. Int J Livest Res 2016; 6(1): 21-26. http://dx.doi. org/10.5455/ijlr.20151217082323.

Katakam KK, Thamsborg SM, Dalsgaard A, Kyvsgaard NC, Mejer H. Environmental contamination and transmission of Ascaris suum in Danish organic pig farms. Parasit Vectors 2016; 9(1): 80. http://dx.doi. org/10.1186/s13071-016-1349-0. PMid:26860206.

Knecht D, Popiolek M, Zalesny G. Does meatiness of pig depend on the level of gastro-intestinal parasites infection? Prev Vet Med 2011; 99(2-4): 234-239. http://dx.doi.org/10.1016/j.prevetmed.2011.01.009. PMid:21334086.

Lai M, Zhou RQ, Huang HC, Hu SJ. Prevalence and risk factors associated with intestinal parasites in pigs in Chongqing, China. Res Vet Sci
2011; 91(3): e121-e124. http://dx.doi.org/10.1016/j.rvsc.2011.01.025. PMid:21349561.

Nejsum P, Thamsborg SM, Petersen HH, Kringel H, Fredholm M, Roepstorff A. Population dynamics of Trichuris suis in trickle-infected pigs. Parasitology 2009; 136(6): 691-697. http://dx.doi.org/10.1017/ S0031182009005976. PMid:19368744.

Nissen S, Poulsen IH, Nejsum P, Olsen A, Roepstorff A, Rubaire-Akiiki $\mathrm{C}$, et al. Prevalence of gastrointestinal nematodes in growing pigs in Kabale District in Uganda. Trop Anim Health Prod 2011; 43(3): $567-$ 572. http://dx.doi.org/10.1007/s11250-010-9732-x. PMid:21088893.

Perfetti DJC, Quintero MEA, Low JLT, Moreno PM. Prevalence of porcine enteric parasites in a rural community from Paraguana Peninsula, Falcon State, Venezuela. Rev Cient Vet 2013; 23(1): 19-25.

Pinto JMS, Costa JO, Souza JCA. Ocorrência de endoparasitos em suínos criados em Itabuna, Bahia, Brasil. Ciênc Vet Tróp 2007; 10(2-3): 79-85.

Pittman JS, Shepherd G, Thacker BJ, Myers GH. Trichuris suis in finishing pigs: case report and review. J Swine Health Prod 2010; 18(6): 306-313.

$\mathrm{R}$ Core Team. A language and environment for statistical computing [online]. Vienna: R Core Team; 2018 [cited 2019 Oct 10]. Available from: https://www.R-project.org/

Radostitis OM, Gay CC, Hinchcliff KWE, Constable PD. Veterinary Medicine: A textbook of the diseases of cattle, horses, sheep, pigs and goats. Philadelphia: Saunders; 2007.

Statistical Analyses System ${ }^{\odot}$ - SAS. University Edition [online]. (CSAS Institute Inc.; 2019 [cited 2019 Set 20]. Available from: https://www. sas.com/en_us/software/university-edition.html

Sowemimo OA, Asaolu SO, Adegoke FO, Ayanniyi OO. Epidemiological survey of gastrointestinal parasites of pigs in Ibadan, Southwest Nigeria. $J$ Public Health Epidemiol 2012; 4(10): 294-298. http://dx.doi.org/10.5897/ JPHE12.042.

Tamboura HH, Banga-Mboko H, Maes D, Youssao I, Traore A, Bayala $\mathrm{B}$, et al. Prevalence of common gastrointestinal nematode parasites in scavenging pigs of different ages and sexes in eastern centre province, Burkina Faso. Onderstepoort J Vet Res 2006; 73(1): 53-60. http://dx.doi. org/10.4102/ojvr.v73i1.169. PMid:16715878.

Thamsborg SM, Roepstorff A. Parasite problems in organic livestock production systems and options for control. J Parasitol 2003; 89(Suppl.): 277-284.

Ueno H, Gonçalves PC. Manual para diagnóstico das helmintoses de ruminantes. Tokyo: Japan International Cooperation Agency; 1998.

Vaz RZ, Restle J, Pacheco PS, Vaz FN, Alves Filho DC, Brondani IL, et al. Produtividade e eficiência de produçáo de vacas de diferentes grupos genéticos submetidas a pastagens cultivadas no pré ou pós-parto. Semina: Ciênc Agrár 2014; 35(5): 2697-2708. http://dx.doi.org/10.5433/1679$0359.2014 \mathrm{v} 35 \mathrm{n} 5 \mathrm{p} 2697$.

Vlaminck J, Levecke B, Vercruysse J, Geldhof P. Advances in the diagnosis of Ascaris suum infections in pigs and their possible applications in humans. Parasitol 2014; 141(14): 1904-1911. http://dx.doi.org/10.1017/ S0031182014000328. PMid:24775944. 